University of Nebraska - Lincoln

DigitalCommons@University of Nebraska - Lincoln

$5-1-2005$

\title{
The Communication Studies Researcher and the Communication Studies Indexes
}

David C. Tyler

University of Nebraska - Lincoln, dtyler2@unl.edu

Signe Swanson

University of Nebraska - Lincoln, sboudreau3@unl.edu

Susan M. Leach

University of Nebraska-Lincoln, sleach1@unl.edu

Follow this and additional works at: https://digitalcommons.unl.edu/libraryscience

Part of the Library and Information Science Commons

Tyler, David C.; Swanson, Signe; and Leach, Susan M., "The Communication Studies Researcher and the Communication Studies Indexes" (2005). Faculty Publications, UNL Libraries. 122.

https://digitalcommons.unl.edu/libraryscience/122

This Article is brought to you for free and open access by the Libraries at University of Nebraska-Lincoln at DigitalCommons@University of Nebraska - Lincoln. It has been accepted for inclusion in Faculty Publications, UNL Libraries by an authorized administrator of DigitalCommons@University of Nebraska - Lincoln. 


\title{
The Communication Studies Researcher and the Communication Studies Indexes
}

\author{
David C. Tyler \\ Signe O. Boudreau \\ Susan M. Leach
}

\begin{abstract}
The existence of widely available large, multi-subject, online databases calls into question the necessity for small, disciplinespecific indexes to support research. This study attempts to determine whether the online Communication Studies indexes provide access to the journal literature that researchers in the field actually cite and whether, where the current journal literature is concerned, that access is in any way superior to that provided by large, multi-subject, online indexes. [Article copies available for a fee from The Haworth Document Delivery Service: 1-800-HAWORTH. E-mail address: <docdelivery@haworthpress.com> Website: <http://www.HaworthPress.com> @ 2005 by The Haworth Press, Inc. All rights reserved.]
\end{abstract}

KEYWORDS. Communication studies, indexes, databases, evaluation, cross-database comparison

David C. Tyler is Reference Librarian and Sociology and Anthropology and Geography Departmental Liaison, 225-D Love Library, University of Nebraska-Lincoln, Lincoln, NE 68488-4100 (E-mail: dtyler2@unl.edu).

Signe O. Boudreau is Reference Librarian and Communication Studies, Journalism and Mass Communications Departmental Liaison, N219 Love Library, University of Nebraska-Lincoln, Lincoln, NE 68488-4100 (E-mail: sswanson3@unl.edu).

Susan M. Leach is Project Assistant and Coordinator, Introduction to Library Research Course, LI 110 Office, Love Library, University of Nebraska-Lincoln, Lincoln, NE 68488-4100 (E-mail: sleach1@unl.edu).

Behavioral \& Social Sciences Librarian, Vol. 23(2) 2005

Available online at http://www.haworthpress.com/web/BSSL

(C) 2005 by The Haworth Press, Inc. All rights reserved.

Digital Object Identifier: 10.1300/J103v23n02_02 


\section{INTRODUCTION}

In the current climate of rising prices and stagnant or shrinking library budgets, many, if not most, academic libraries have been forced to prune their collections of journals, indexes, and electronic databases. Many of the librarians involved in this activity have been rightly worried that they may be adversely affecting the colleges and disciplines they were meant to serve by having to deny researchers quick, easy access to discipline-specific resources. In our own case, while in the midst of a large serials prioritization project, we wondered if we were harming our university's Communication Studies researchers by not providing access to an online database specific to their discipline. After all, we supply access to most of the other social science disciplines with degree programs on campus: Psychology has PsycInfo, Sociology has Sociological Abstracts, and so forth. To this end, we determined to discover whether the Communication Studies indexes available would be useful to Communication Studies researchers, both in terms of providing overall access to the journal literature and of providing superior access to the current journal literature in the field. ${ }^{1}$

The usual methods for reviewing the suitability of indexes tend to follow one of two paths: (1) the reviewers assemble a list of core titles from the field and/or important titles from relevant fields and check to see how well the indexes being evaluated cover them (for an excellent example of this type of core-literature review, see Sutton and Foulke 1999); or (2) the reviewers perform a variety of subject and/or keyword searches in the database(s) to determine how well particular topics are covered by the database(s) under review (for an example of this type of topical review, see Clement and Ogburn 1995).

As our aim was not to determine whether the core literature or a particular subject was well covered, we proceeded a bit differently. Much as one would for the first type of review, we assembled a list of core Communication Studies titles and important journals from related disciplines from a variety of sources: Carolyn Mueller's "Communication Journals" (1984); the fourth edition of Rubin, Rubin, and Piele's Communication Research: Strategies and Sources (1996); Block and Bracken's Communication and the Mass Media (1991); and, of course, a recent edition of Magazines for Libraries (LaGuardia 2002). From this assembled list we selected likely, widely-held titles from several call number ranges. ${ }^{2}$ From each of the titles, we copied the "Refer- 
ences" or "Works Cited" pages from an issue's articles, usually from the first available issue of the year 2000. ${ }^{3}$ Then, after removing duplicate citations from consideration, we selected all of the citations that appeared to be to academic/scholarly journals. This list of citations to academic/scholarly journals (6,170 citations out of roughly 15,773$)$ would serve as the basis of our examination of the efficacy of the Communication Studies indexes. (For quick reference for the numbers used in each section of the paper, see Appendix I; for information on the selected journals and citations, see Appendix II.)

Our purpose in examining the indexes was twofold. First, we hoped to determine whether the Communication Studies indexes selected for review would be useful to the Communication Studies researcher. To do this, we used the journal citations to determine as best we could whether the journal literature actually cited by Communication Studies researchers was likely to be recorded by the indexes in question. Second, we hoped to discover whether the Communication Studies indexes or larger, multi-subject databases would be more useful to the Communication Studies researcher wishing to review the current literature. To accomplish this, we used a subset of the assembled list of journal citations, the citations from roughly five years before the articles in our set were submitted for review, as well as those "in-press" items that were published no later than the year in which our selected references pages were published (i.e., 2000), and compared how well the Communication Studies indexes covered those items versus how well the larger, multi-subject online indexes covered them. So, in perusing the results of our study, the reader should keep in mind that our aim was not to determine how well the core journal literature or a particular topic in the core journal literature for Communication Studies is covered by the Communication Studies indexes. Rather, our purpose was to determine how well these indexes cover the journal literature actually used by Communication Studies researchers to produce their discipline's core literature, and to determine whether these smaller, discipline-specific indexes are necessary to sustain a productive group of researchers in Communication Studies.

\section{THE INDEXES AND DATABASES}

For our comparison we selected three indexes specific to communication studies: Communication Abstracts, ComIndex, and ComAbstracts. 
For many years Communication Abstracts was the sole subject-specific index for the field, although its limitations had not gone unnoticed. ComIndex and ComAbstracts are provided by the non-profit Communication Institue for Online Scholarship (CIOS), and their introduction in the early 1990s offered communication studies researchers additional search options.

We also selected a variety of multi-subject indexes. Two, Ingenta and ArticleFirst, are largely table of contents databases that offer little or no abstracting. Academic Search Elite and OmniFile Full Text Select are full-text databases focused largely on general undergraduate research. Web of Science is a widely-used citation-search database.

For each of the indexes we developed a brief comparative profile that included the claimed coverage (selective or comprehensive), the index's developer, topics covered, years covered, estimate of total number of citations, number of citations added and at what interval, and available formats:

\section{ComAbstracts}

Claimed coverage: Comprehensive indexing and abstracting; subset of ComIndex

Party responsible: Communication Institute for Online Scholarship (CIOS)

Topics covered: Communication studies, rhetoric, journalism, mass communication, and speech

Years covered: Coverage varies by publication; earliest is 1974, but typically coverage dates back to the 1980s and 1990s

Total number of citations: Approximately 17,000 records

Update frequency and number of citations added: Throughout the year with 1,300-1,600 records added annually

Available formats: Web-based (CIOS Support Staff "About the ..." and "Comparing CIOS ... ; CIOS/Comserve support staff 2003)

\section{ComIndex}

Claimed coverage: Comprehensive author and title indexing

Party responsible: Communication Institute for Online Scholarlship (CIOS) 
Topics covered: Communication studies, rhetoric, journalism, mass communication, and speech

Years covered: A few titles are indexed back to their first volume in the 1960s, but most are indexed from the first issue or 1970, whichever is most recent, and extend through the most recent volume completed by spring 2001

Total number of citations: Approximately 40,000 records

Update frequency and number of citations added: Yearly with between 1,800-2,500 records added

Available formats: DOS-based (CIOS Support Staff "ComIndex Software ...”; CIOS/Comserve support staff 2003)

\section{Communication Abstracts}

Claimed coverage: Selective indexing and abstracting

Party responsible: Sage Publications, edited by Thomas F. Gordon, Temple University's School of Communications and Theater

Topics covered: General communication, mass communication, advertising and marketing, broadcasting, communication theory, interpersonal and intrapersonal communication, small group communication, organizational communication, journalism, public relations, radio, public opinion, speech, and television

Years covered: 1978-present

Total number of citations: Over 35,000 records

Update frequency and number of citations added: Bimonthly with approximately 300 records added (600 added beginning 2004)

Available formats: Web-based and print (Cambridge Scientific Abstracts. "Fact Sheet ...")

\section{Academic Search Elite}

Claimed coverage: Comprehensive indexing and abstracting

Party responsible: EBSCO 
Topics covered: Social sciences, humanities, education, computer sciences, engineering,physics, chemistry, language and linguistics, arts and literature, medical sciences, and ethnic studies

Years covered: 1985-present, depending on title

Total number of citations: Over 6.6 million records

Update frequency and number of citations added: Daily with approximately 1,200 records added

Available formats: Web-based (EBSCO Publishing 2003 and EBSCO Publishing Technical Support 2003)

\section{ArticleFirst}

Claimed coverage: Comprehensive table of contents indexing, no abstracting; formerly known as ContentsFirst

Party responsible: OCLC

Topics covered: Business, humanities, medicine, popular culture, science, social science, and technology

Years covered: 1990-present

Total number of citations: Over 12.7 million records

Update frequency and number of citations added: Daily

Available formats: Web-based (OCLC “ArticleFirst [OCLC]”)

\section{Ingenta}

Claimed coverage: Comprehensive table of contents indexing, selective abstracting; combination of Ingenta and Uncover databases

Party responsible: Ingenta

Topics covered: Academic and professional content, with focus on scientific and research literature

Years covered: 1988-present, depending on title

Total number of citations: Over 11 million citations

Update frequency and number of citations added: Daily with undetermined number of records added 
Available formats: Web-based (Ingenta "About Ingenta" and Bisbee 2003)

\section{OmniFile (Full Text, Select Edition)}

Claimed coverage: Cover-to-cover indexing and abstracting; combines contents of six subject-specific Wilson databases, as well as the journals in five other databases to which Wilson has full-text rights

Party responsible: HW Wilson

Topics covered: Education, general science, humanities, social sciences, business, applied science and technology, biology, agriculture, law, and library and information science

Years covered: 1982-present (indexing), 1984-present (abstracting), and 1994-present (full-text)

Total number of citations: Over 975,000 records

Update frequency and number of citations added: Daily (Web) with approximately 700 records added

Available formats: Web-based and CD-ROM ("Wilson OmniFile ..." and Seiler 2003)

\section{Web of Science}

Claimed coverage: Cover to cover indexing and abstracting; combination of the contents of the Science Citation Index, the Social Science Citation Index, and the Arts and Humanities Citation Index

Party responsible: Thomson ISI

Topics covered: Social sciences, sciences, and arts and humanities.

Years covered: 1945-present (SCI); 1956-present (SSCI), 1975present (A\&HSC)

Total number of citations: Over 1.1 million records indexed each year

Update frequency and number of citations added: Weekly with approximately 23,500 records added 
Available formats: Web-based, online (e.g., DIALOG), and print (Thomson ISI 2003 and ISI Help Desk-Americas 2003)

\section{SEARCHING THE DATABASES}

\section{Communication Abstracts}

We did not have access to the searchable online version of Communication Abstracts, so coverage of the cited journal articles by Communication Abstracts was confirmed by searching for a listing of the cited journal article's author(s) in the "Cumulative Author Index" which appears in the sixth and final issue of each printed volume. To increase the likely accuracy of our searches, we looked for up to three last names and first and second initials of co-authors for co-authored works, and for journal articles by a single author, we reviewed every listed instance of the author's last name (e.g.: Brown, A; Brown, B; etc.) In some instances, we also reviewed entries where misspellings could likely occur (e.g.: Cohen, A and Cohn, A). For each citation, the Cumulative Author Index for the year in which the cited journal article was published and the Cumulative Author Indexes of the subsequent two years were searched. Later indexes were not searched as we were of the opinion that taking more than two years to index an item violated the tenets of timely indexing. It is our experience that patrons do not select a 1997 index if they are interested in what was published in 1994. Citations that were found were counted as "hits," and citations that were not, were counted as "misses."

Despite our best efforts, however, there were bound to be inaccuracies in the data we collected. For instance, though we did our best to correct citations that provided incorrect information, there were undoubtedly some citations in our lists that provided so much inaccurate information that we were unable to correct them. Also, we did happen across citations to journal articles that were indexed by Communication Abstracts three or more years after their publication, but we did not include them as "hits."

Lastly, while working on the second part of the project, we discovered that there were at least a few journal articles' citations that we had been unable to find in our searches of the several "Cumulative Author" indexes that were listed as being indexed by Communication Abstracts by the multi-subject online indexes that covered Communication Abstracts. A quick search of the appropriate issues' individual "Author In- 
dex" revealed that, in most instances, the multi-subject online index was correct and Communication Abstracts' "Cumulative Author" indexes were incorrect. We did not, however, correct those inaccuracies as they were very few, given the large number of citations with which we were working, and because correcting them would have created something of a schism in our data and would have led to the "1994-and-after" subset being collected with a different and more accurate means than the data that we had collected for the citations to pre-1994 journal articles. We felt that would have too muddied the waters of our project, especially when one considers that for the later journal articles we would have been relying on an index other than Communication Abstracts to provide access to Communication Abstracts' content, which would have suggested that to some extent other indexes index Communication Abstracts better than it does itself. The data for Communication Abstracts should therefore be taken as strongly suggestive of the extent of the index's coverage rather than as an absolutely accurate tallying.

\section{ComIndex and ComAbstracts}

Because we also did not have access to the electronic version of the CIOS's two indexes, we confirmed their coverage by comparing the titles of the journals cited and the dates given in the individual citations to the two title-coverage lists for the indexes, which were available online (CIOS Support Staff "Indexes to ..." and "About the ..."). If a cited title appeared in the indexes' lists and if its year of publication fell within the date range provided in the indexes' lists, then a "hit" was recorded; if not, then a "miss" was recorded.

As this method is the most limited in terms of the opportunities for search redundancy and correction that it allows, we would hazard that our findings for these indexes are most likely to be the least accurate in terms of their absolute accuracy. However, if the CIOS takes some pains to ensure that its title lists and scope notes are accurate, and there seems to be no reason why they should not, the results reported herein should be fairly accurately suggestive of the extent of the indexes' coverage of the literature actually cited by Communication Studies researchers.

\section{The Multi-Subject Databases}

In order to increase the accuracy of our searches for the journal citations in the several multi-subject databases, each citation was searched 
for up to three times in three different fashions. The first search involved employing a few key terms from the cited articles' titles in combination with the author's name or authors' names in a combined keyword search of the "title" and "author" fields. If the first search failed, a second search was conducted using other salient terms from the cited articles' titles in a keyword search of the databases" "title" field. If this second search failed, a third search was conducted by employing the databases' "Browse," "Browse Publications," or "Publications" option to turn up records for the appropriate volume and/or issue of the journal in which the cited article appeared. If a record for the cited item appeared during any of the three searches, a "hit" was recorded; if not, a "miss."

\section{RESULTS, PART I: \\ THE FULL LIST \\ AND THE COMMUNICATION STUDIES INDEXES}

Given the degree to which the several Communication Studies researchers we talked with promoted the multi-disciplinary nature of their research, and the field's sense of itself as a haven for interdisciplinary work (for example, author Robert T. Craig, in a recent article on the field, began his remarks thusly: "Communication theory is enormously rich in the range of ideas that fall within its nominal scope" [1999]), our expectation for the results of this first part of our project was that Communication Abstracts would do rather well. Its editor's recognition that "the literature of communication is widely scattered [and that] [t]he potential outlets for such research encompass virtually every discipline dealing with human behavior" (Gordon 1978), and the abstracting journal's resultant and continuing commitment to providing "[a] comprehensive source of information about communication-related articles, reports, and books from a variety of publishers, research institutions, and information sources" ("Communication Abstracts ..." 2002) seemed to us to be the best-suited attitude for the purported nature of the discipline.

We expected that the CIOS' indexes, given the organization's editorial decision to cover just "articles published in the primary professional literature of the communication(s) field" (CIOS Support Staff "About the ..."), would do considerably less well because of their more restrictive approach to indexing the field. Our specific expectation for ComAbstracts, as it merely provides value-adding abstracting 
to a portion of the core literature covered by ComIndex, was that it would do very poorly indeed. ${ }^{4}$ We felt that at best, ComIndex, and to a lesser extent, ComAbstracts, might give comparable or slightly superior coverage to that portion of the cited journal literature that appeared in traditional Communication Studies journals, but we very much expected that Communication Abstracts would greatly outperform both indexes across the board, given the aforementioned seeming superiority and suitability of its approach.

\section{Results for the Communication Indexes}

Our initial findings indicated that our expectations were almost entirely incorrect. As Table I shows, Communication Abstracts indexed just over one-fifth of the citations, or $21.3 \%$, just 117 more than ComAbstracts did. ${ }^{5}$ ComIndex, with just over $30 \%$, indexed almost $10 \%$ more of the citations, although we feel we should point out that the actual difference in the number of citations indexed (549) was not all that great. Still, we must admit that we were very surprised that the three Communication Studies indexes, as a group, indexed on average less than $25 \%$ of the journal literature cited by several researchers publishing in the selected core Communication Studies titles.

\section{Results for the Communication Indexes by the Cited Articles' Decade of Publication}

Our first thought was that perhaps at least in part the dearth in hits was caused by the dates of publication for some of the cited journal articles. Nearly $5 \%$ of the cited journal articles were published prior to or during the 1960s, and just over 10\% were published during the 1970s. Communication Abstracts, of course, did not begin indexing until 1978 and does not offer retrospective indexing; ComIndex and ComAbstracts offer some restrospective indexing for the early 1970s and late 1960s, but they hardly provide full indexing for the period; so one could expect the number of hits for the earlier decades to be low and the number of hits for the later decades that make up the meat of all three indexes' coverage to be considerably higher.

As the results of categorizing the cited journal articles by decade of publication in Table II show, the actual effect is a bit more ambiguous, and certainly more disappointing, than expected. Both Communication Abstracts and ComIndex show slight jumps in the percentage of articles indexed for the 1980s and 1990s, but not particularly impressive ones. 
TABLE I. Citations Covered by the Communication Studies Indexes $(n=6,170)$

\begin{tabular}{|l|c|c|}
\hline INDEX & HITS & $\%$ \\
\hline Communication Abstracts & 1,312 & 21.3 \\
\hline ComIndex & 1,861 & 30.2 \\
\hline ComAbstracts & 1,195 & 19.4 \\
\hline
\end{tabular}

TABLE II. Citations Covered by the Communication Studies Indexes by Decade $(n=6,170)$

\begin{tabular}{|l|c|c|c|c|c|c|c|c|c|c|}
\hline & \multicolumn{2}{|c|}{$\begin{array}{c}1960 \mathrm{~s} \& \text { prior } \\
(\mathrm{n}=294)\end{array}$} & \multicolumn{2}{c|}{$\begin{array}{c}1970 \mathrm{~s} \\
(\mathrm{n}=634)\end{array}$} & \multicolumn{2}{c|}{$\begin{array}{c}1980 \mathrm{~s} \\
(\mathrm{n}=1,807)\end{array}$} & \multicolumn{2}{c|}{$\begin{array}{c}1990 \mathrm{~s} \\
(\mathrm{n}=3,373)\end{array}$} & \multicolumn{2}{c|}{$\begin{array}{c}2000 \\
(\mathrm{n}=57)\end{array}$} \\
\hline \multicolumn{1}{|c|}{ INDEX } & HITS & $\%$ & HITS & $\%$ & HITS & $\%$ & HITS & $\%$ & HITS & $\%$ \\
\hline $\begin{array}{l}\text { Communication } \\
\text { Abstracts }\end{array}$ & 0 & 0.0 & 62 & 9.8 & 429 & 23.7 & 809 & 24.0 & 12 & 21.1 \\
\hline ComIndex & 5 & 1.7 & 213 & 33.6 & 544 & 33.3 & 1,076 & 31.9 & 23 & 40.4 \\
\hline ComAbstracts & 6 & 2.0 & 26 & 4.1 & 261 & 14.4 & 880 & 26.1 & 22 & 38.6 \\
\hline
\end{tabular}

ComAbstracts, interestingly enough, shows a sizeable drop (nearly 5\%) for articles from the 1980s and a nearly opposite increase (about 7\%) for articles from the 1990s. Despite the disparity, ComAbstracts' average change for the two decades, however, is well within range of the 2-3\% increase noted for the other two titles. ${ }^{6}$

Perhaps the greatest pleasant surprise uncovered by categorizing the cited journal articles by decade is ComIndexes' coverage of the 1970s. All three indexes exhibited the expected poor performance for titles published in the 1960s and prior, and Communication Abstracts and ComAbstracts, as expected, did not do well in the 1970s, though one might argue that Communication Abstracts performed better than could be expected, at just under $10 \%$, when one takes into account that it was actively indexing only for the last two years of the 1970s. ComIndex, however, actually showed a $3 \%$ increase in the percentage of journal articles indexed for the 1970s. So, again, ComIndex actually did a bit better than expected, despite the seemingly restrictive nature of its indexing strategy, and Communication Abstracts continued to under perform with respect to our expectations, indexing a bit less than $25 \%$ of the cited journal literature selected, comfortably outperforming ComAbstracts in the 1970s and 1980s, but being outperformed by ComAbstracts in the 1990s. 


\section{Results for the Communication Indexes by the Citing Journals' Call Letter Group}

Our next thought was that perhaps the distribution of the selected journals across several call letter ranges, may have negatively impacted the performance of the three Communication Studies indexes, that perhaps coverage would be significantly better for the journal literature cited in the ranges traditionally associated with Communication Studies, and worse for the cited journal literature in the other ranges. We also suspected, given the differences in their indexing strategies, that ComIndex and ComAbstracts might greatly out perform Communication Abstracts in the call letter ranges traditionally associated with Communication Studies, "P" and "PN," but that Communication Abstracts would perform considerably better in the other ranges, "B," "H," and with the "Miscellaneous" grouping, the grouping into which we placed those titles that did not neatly fit into one of the other four groups (for the actual call letters assigned to each title, see Appendix II).

As Table III shows, what we had suspected turned out to be, and not to be, the case. ComIndex and ComAbstracts had sizeable increases in their percentages of coverage of the cited journal literature for items appearing in journals with "P" 7 and "PN" call numbers, and their percentages of coverage for the cited journal literature in the other three ranges/groupings showed a commensurate drop.

The effect that categorizing the cited journal literature by the call number ranges/groupings of the citing journals had upon Communication Abstracts, however, was a bit of a puzzle. Communication Abstracts showed a small upward jump from its average for the "P" and "PN" call number ranges, though nothing like the jumps exhibited by ComIndex and ComAbstracts, which was much as we had predicted, but its behavior in the other ranges/groupings was not quite what we had

TABLE III. Citations Covered by the Communication Studies Indexes by Call Letter Group $(n=6,170)$

\begin{tabular}{|c|c|c|c|c|c|c|c|c|c|c|}
\hline \multirow[b]{2}{*}{ INDEX } & \multicolumn{2}{|c|}{$\begin{array}{l}\text { "B" Group } \\
(\mathrm{n}=516)\end{array}$} & \multicolumn{2}{|c|}{$\begin{array}{l}\text { "H" Group } \\
(\mathrm{n}=1,636) \\
\end{array}$} & \multicolumn{2}{|c|}{$\begin{array}{l}\text { "P" Group } \\
(\mathrm{n}=1,918) \\
\end{array}$} & \multicolumn{2}{|c|}{$\begin{array}{l}\text { "PN" Group } \\
(\mathrm{n}=1,319)\end{array}$} & \multicolumn{2}{|c|}{$\begin{array}{c}\text { "Misc" Group } \\
(\mathrm{n}=781)\end{array}$} \\
\hline & HITS & $\%$ & HITS & $\%$ & HITS & $\%$ & HITS & $\%$ & HITS & $\%$ \\
\hline $\begin{array}{l}\text { Communication } \\
\text { Abstracts }\end{array}$ & 20 & 3.9 & 380 & 23.2 & 476 & 24.8 & 379 & 28.7 & 57 & 7.3 \\
\hline Comlndex & 17 & 3.3 & 288 & 17.6 & 780 & 40.7 & 688 & 52.2 & 88 & 11.3 \\
\hline ComAbstracts & 13 & 2.5 & 168 & 10.3 & 524 & 27.3 & 437 & 33.1 & 53 & 6.8 \\
\hline
\end{tabular}


hoped. Communication Abstracts did show a slight upward jump from its average percentage in Table I for the " $\mathrm{H}$ " call letter group, but it certainly did not greatly outdo ComIndex in this range. In the other ranges/groupings, Communication Abstracts, despite its more inclusive indexing strategy, performed equally to, or worse than, the other two indexes. While we do not wish to overstate the case, these results seem to indicate that the three indexes, despite their differing indexing strategies, may well be indexing largely the same literature and that Communication Abstracts either may not be going far enough afield to differentiate itself from ComIndex and ComAbstracts or may be going too far afield, from the perspective of the Communication Studies researchers employed here, and may be providing access to literature that is not being cited in the field's core literature.

\section{Unique and Shared Hits for the Communication Studies Indexes}

In the interest of at least partially examining this last point, we decided to look at the number of unique hits provided by each index in one-to-one comparison and in comparison with the indexes as a group. As Tables IV-a and -b show, Communication Abstracts and ComIndex actually do cover a great deal of the same literature as do Communication Abstracts and ComAbstracts. Our expectation was that Communication Abstracts' indexing strategy would have resulted in its having a greater number of unique hits than the other indexes, or at least that a greater percentage of its hits would be unique, but such is clearly not the case. In one-to-one comparison with Communication Abstracts in Table IV-a, ComIndex has nearly as many unique hits $(49.2 \%)$ as hits in common $(50.8 \%)$, while less than one-third of Communication Abstracts' hits are unique $(28 \%)$ and over two-thirds are hits in common $(72 \%)$ with ComIndex. In fact, the Communication Abstracts unique/shared split is almost exactly 50/50 when compared against ComAbstracts. When all three indexes hits were examined for uniqueness as a group, as they were in Table IV-b, Communication Abstracts has fewer absolutely unique hits than ComIndex does, despite the fact that ComIndex and ComAbstracts have most of their indexed journal titles in common. Whatever the benefits of Communication Abstracts' indexing strategy may be in theory, in actual practice they do not appear to manifest themselves very strongly, at least not from the perspective of the selected Communication Studies researchers.

ComIndex and ComAbstracts, of course, are much the same index, with the one having more indexed titles and no abstracting and the other 
TABLE IV-a. One-to-One Cross-Index Comparisons: Unique Hits and Shared Hits for the Communication Studies Indexes

\begin{tabular}{|c|c|c|c|c|c|c|}
\hline INDEX & \multicolumn{2}{|c|}{$\begin{array}{c}\text { Communication } \\
\text { Abstracts } \\
(\mathrm{n}=1,312)\end{array}$} & \multicolumn{2}{c|}{$\begin{array}{c}\text { ComIndex } \\
(\mathrm{n}=1,861)\end{array}$} & \multicolumn{2}{c|}{$\begin{array}{c}\text { ComAbstracts } \\
(\mathrm{n}=1,195)\end{array}$} \\
\hline & $\begin{array}{c}\text { UNIQUE } \\
\text { HITS }\end{array}$ & $\begin{array}{c}\text { SHARED } \\
\text { HITS }\end{array}$ & $\begin{array}{c}\text { UNIQUE } \\
\text { HITS }\end{array}$ & $\begin{array}{c}\text { SHARED } \\
\text { HITS }\end{array}$ & $\begin{array}{c}\text { UNIQUE } \\
\text { HITS }\end{array}$ & $\begin{array}{c}\text { SHARED } \\
\text { HITS }\end{array}$ \\
\hline $\begin{array}{c}\text { vs. Communication } \\
\text { Abstracts }\end{array}$ & -- & -- & 916 & 945 & 526 & 669 \\
\hline vs. ComIndex & 367 & 945 & -- & -- & 7 & 1,188 \\
\hline vs. ComAbstracts & 643 & 669 & 673 & 1,188 & -- & -- \\
\hline
\end{tabular}

TABLE IV-b. Full Cross-Index Comparisons: Total Unique Hits for the Communication Studies Indexes

\begin{tabular}{|c|c|c|}
\hline INDEX & TOTAL UNIQUE HITS & \% OF TOTAL HITS \\
\hline $\begin{array}{c}\text { Communication Abstracts } \\
(\mathrm{n}=1,312)\end{array}$ & 366 & 27.9 \\
\hline $\begin{array}{c}\text { Comlndex } \\
(\mathrm{n}=1,861)\end{array}$ & 396 & 21.3 \\
\hline $\begin{array}{c}\text { ComAbstracts } \\
(\mathrm{n}=1,195)\end{array}$ & 6 & 0.5 \\
\hline
\end{tabular}

having abstracting but slightly fewer indexed titles, so the sorts of comparisons that we made above involving Communication Abstracts probably would not be pertinent. However, such a comparison could give one an opportunity to investigate the effect upon the utility of the indexes that indexing fewer titles in favor of a value-adding abstracting service has. As one can see by glancing at Table IV-a, ComAbstracts' indexing 18 fewer titles (21.7\% fewer) than ComIndex covers results in its covering 673 fewer cited articles than ComIndex, or just over one-third (36.2\%) of ComIndex's total coverage. While we are not familiar with the reasoning behind and the logistics of providing the two indexes, we are inclined to question why CIOS goes to the effort of providing two nearly identical indexes. Neither, as they stand, with the one not providing abstracting and with the other providing one-third less coverage with roughly one-fifth fewer covered titles in this study, seems particularly attractive. It seems to us that equal or superior service could be provided with less effort if the two were simply combined into a single index with abstracting. 


\section{RESULTS, PART II: \\ CITATIONS TO THE CURRENT JOURNAL LITERATURE FOR COMMUNICATION STUDIES AND MULTI-SUBJECT DATABASES}

As a follow-up to Part I of our evaluation, we hoped to discover how useful the Communication Studies indexes would prove to the Communication Studies researcher as gateways into the current journal literature, as opposed to a handful of the large, multi-subject, online databases available. ${ }^{8}$ To this end, we selected those cited articles published in the roughly five years before the selected citing articles were submitted and/or published (i.e., 2,126 cited articles published in 1994 and after, up to and including in-press items that were published in 2000), and we again searched the indexes to determine what percentage of the total were covered by the various indexes. Our expectation was that the largest multi-subject databases would produce the most "hits," though we did not expect them to completely overwhelm the Communication Studies indexes. Our expectation was that the larger indexes would be more likely to catch articles from journals outside of Communication Studies proper but that, with their greater and more in-depth coverage of the discipline, the Communication Studies indexes would cover their field's journals nearly as well.

\section{Result for the Communication Studies and Multi-Subject Databases}

As Table V clearly shows, with the rather startling exception of the H.W. Wilson database OmniFile, the larger databases did indeed overwhelm the Communication Studies indexes, with the largest three indexes each covering roughly two-thirds or more of the cited articles and the Communication Studies indexes covering roughly one-third or less. Interestingly, each of the Communication Studies indexes covered a greater percentage of the available citations this time around, with ComAbstracts making by far the largest increase (from an average of $19.4 \%$ in Table I to $29 \%$ here). No doubt, the increases for ComIndex and ComAbstracts may in part be attributed to their providing more comprehensive indexing to the 1990's volumes of the journals that they cover than to the 1960's and 1970's issues; Communication Abstracts' increase might to some slight degree be attributed to its having increased the number of titles that it indexes and the number of citations and abstracts that it provides over the course of its indexing life. ${ }^{9}$ De- 
TABLE V. Citations from the Current Literature Covered by the Communication Studies and the Multi-Subject Databases $(n=2,126)$

\begin{tabular}{|l|c|c|}
\hline INDEX & HITS & $\%$ \\
\hline Communication Abstracts & 532 & 25.0 \\
\hline ComIndex & 726 & 34.1 \\
\hline ComAbstracts & 618 & 29.1 \\
\hline ArticleFirst & 1,621 & 76.2 \\
\hline Academic Search Elite & 1,021 & 48.0 \\
\hline OmniFile & 105 & 4.9 \\
\hline Web of Science & 1,477 & 69.5 \\
\hline Ingenta & 1,655 & 77.8 \\
\hline
\end{tabular}

spite their increases in coverage, however, the Communication Studies indexes performed woefully when compared to the large multi-subject databases available, with, as mentioned above, the exception of OmniFile. It is difficult to ascertain from the results offered here what OmniFile is intended to index, but whatever it may be, it would appear that Communication Studies is not an area of particular focus.

\section{Result for the Communication Studies and Multi-Subject Databases by Call Letter Group}

Of course, the results displayed in Table V are not entirely fair to the Communication Studies indexes. Their purpose is to provide in-depth coverage to Communication Studies, while the purpose of the multisubject databases is to provide broad coverage for many disciplines. Though the Communication Studies indexes' results above were disappointing, they were not unexpected given the databases' obvious differences in size and scope. One might hope, however, that the Communication Studies indexes would be competitive with, or even superior to, the multi-subject databases in the area of their focus. To determine whether this might indeed be the case, we again disaggregated our set of citations into the call letters groupings to which the citing journals were assigned, with the expectation that the Communication Studies indexes would perform comparatively well for the "P" and "PN" groupings.

As Table VI shows, the Communication Studies indexes did cover the cited articles from citing journals in the "P" and "PN" groupings to a greater extent than they covered the cited articles from the journals in the other groups, but they were still out-indexed by the multi-subject data- 
TABLE VI. Citations Covered by the Communication Studies Indexes and Multi-Subject Databases by Call Letter Group $(n=2,126)$

\begin{tabular}{|l|c|c|c|c|c|c|c|c|c|c|}
\hline & \multicolumn{2}{|c|}{$\begin{array}{c}\text { "B" Group } \\
(\mathrm{n}=164)\end{array}$} & \multicolumn{2}{c|}{$\begin{array}{c}\text { "H" Group } \\
(\mathrm{n}=552)\end{array}$} & \multicolumn{2}{c|}{$\begin{array}{c}\text { "P" Group } \\
(\mathrm{n}=685)\end{array}$} & \multicolumn{2}{c|}{$\begin{array}{c}\text { "PN" Group } \\
(\mathrm{n}=428)\end{array}$} & \multicolumn{2}{c|}{$\begin{array}{c}\text { "Misc" Group } \\
(\mathrm{n}=297)\end{array}$} \\
\hline \multicolumn{1}{|c|}{ INDEX } & HITS & $\%$ & HITS & $\%$ & HITS & $\%$ & HITS & $\%$ & HITS & $\%$ \\
\hline $\begin{array}{l}\text { Communication } \\
\text { Abstracts }\end{array}$ & 3 & 1.8 & 136 & 24.6 & 198 & 28.9 & 165 & 38.6 & 30 & 10.1 \\
\hline ComIndex & 6 & 3.7 & 129 & 23.4 & 316 & 46.1 & 236 & 55.1 & 39 & 13.1 \\
\hline ComAbstracts & 5 & 3.0 & 87 & 15.8 & 275 & 40.1 & 215 & 50.2 & 36 & 12.1 \\
\hline ArticleFirst & 120 & 73.2 & 421 & 76.3 & 534 & 78.0 & 327 & 76.4 & 219 & 73.7 \\
\hline $\begin{array}{l}\text { Academic } \\
\text { Search Elite }\end{array}$ & 92 & 56.1 & 154 & 27.9 & 393 & 57.4 & 276 & 64.5 & 106 & 35.7 \\
\hline OmniFile & 3 & 1.8 & 56 & 10.1 & 14 & 2.0 & 21 & 4.9 & 11 & 3.7 \\
\hline $\begin{array}{l}\text { Web of } \\
\text { Science }\end{array}$ & 127 & 77.4 & 366 & 66.3 & 479 & 69.9 & 278 & 65.0 & 227 & 76.4 \\
\hline Ingenta & 55 & 33.5 & 439 & 79.5 & 558 & 81.5 & 365 & 85.3 & 238 & 80.1 \\
\hline
\end{tabular}

bases, even in the "P" and "PN" groups. ${ }^{10}$ ComIndex and ComAbstracts performed very respectably with the "P" and "PN" groups. One might even say that they performed outstandingly well when one considers how comparatively few journals they cover and how very close they came to equaling the much larger Academic Search Elite's and Web of Science's coverage for those call letter groups. However, they were still outperformed in the "P" and "PN" groups, and were roundly outperformed in the other call letter groups. Communication Abstracts' performance, once again, was relatively poor across the board. One would, therefore, with the results from Table V and Table VI in hand, find it difficult to make a strong case for the Communication Studies indexes with respect to the coverage that they offer to the Communication Studies researcher. The multi-subject databases appear to offer superior coverage both within and without Communication Studies proper.

\section{Unique and Shared Hits for the Communication Studies Indexes and Multi-Subject Databases}

To salvage the argument in favor of specialized Communication Studies indexes would, at this point, seem largely impossible. However, we supposed that there might be two arguments that one might still advance in favor of the Communication Studies indexes: (1) that, in head-to-head cross-database comparisons they might, with their greater 
in-depth coverage of Communication Studies, cover a large number of citations not covered by a particular multi-subject database; and (2) that, again with their greater in-depth coverage of Communication Studies, they might cover a large number of citations not covered by any of the other databases.

For Tables VII-a, -b, and -c, we determined how many of each of the Communication Studies indexes hits were not covered by each of the other indexes when they were compared one-on-one with the other indexes; how many of each of the multi-subject databases' hits were not covered by the Communication Studies indexes when they were compared one-on-one with the other indexes; and how many of each of the indexes' hits were unique when all of the databases were compared to one another, respectively. As one can see, each of the Communication Studies indexes did provide access to some journal literature not covered by the other Communication Studies indexes or by the multi-subject databases. Communication Abstracts, ComIndex, and ComAbstracts all had a surprising number of unique hits when compared to Academic Search Elite and to Web of Science (roughly $20 \%$ to $30 \%$ of their hits were unique), but the Communication Studies indexes were overwhelmed by the much larger ArticleFirst and Ingenta databases.

The Communication Studies indexes' results are much less impressive, however, when one examines the number of unique hits provided by the multi-subject databases when they are compared one-on-one against the Communication Studies indexes in Table VII-b. For most of

TABLE VII-a. One-to-One Cross-Index/Database Comparisons: Unique Hits and Shared Hits for the Communication Studies Indexes When Compared Against Themselves and Against the Multi-Subject Databases $(n=2,126)$

\begin{tabular}{|c|c|c|c|c|c|c|}
\hline & \multicolumn{2}{|c|}{$\begin{array}{c}\text { Communication } \\
\text { Abstracts }(\mathrm{n}=532)\end{array}$} & \multicolumn{2}{c|}{$\begin{array}{c}\text { ComIndex } \\
(\mathrm{n}=726)\end{array}$} & \multicolumn{2}{c|}{$\begin{array}{c}\text { ComAbstracts } \\
(\mathrm{n}=618)\end{array}$} \\
\hline & $\begin{array}{c}\text { UNIQUE } \\
\text { HITS }\end{array}$ & $\begin{array}{c}\text { SHARED } \\
\text { HITS }\end{array}$ & $\begin{array}{c}\text { UNIQUE } \\
\text { HITS }\end{array}$ & $\begin{array}{c}\text { SHARED } \\
\text { HITS }\end{array}$ & $\begin{array}{c}\text { UNIQUE } \\
\text { HITS }\end{array}$ & $\begin{array}{c}\text { SHARED } \\
\text { HITS }\end{array}$ \\
\hline $\begin{array}{c}\text { vs. Communication } \\
\text { Abstracts }\end{array}$ & -- & - & 322 & 404 & 245 & 373 \\
\hline vs. Comlndex & 128 & 404 & -- & -- & 1 & 617 \\
\hline vs. ComAbstracts & 159 & 373 & 109 & 617 & -- & -- \\
\hline vs. ArticleFirst & 59 & 473 & 110 & 616 & 66 & 552 \\
\hline vs. Academic Search Elite & 155 & 377 & 197 & 529 & 120 & 498 \\
\hline vs. OmniFile & 508 & 24 & 698 & 28 & 607 & 11 \\
\hline vs. Web of Science & 117 & 415 & 214 & 512 & 165 & 453 \\
\hline Ingenta & 46 & 486 & 71 & 655 & 49 & 569 \\
\hline
\end{tabular}


TABLE VII-b. One-to-One Cross-Index/Database Comparisons: Unique Hits and Shared Hits for the Multi-Subject Databases When Compared Against the Communication Studies Indexes $(n=2,126)$

\begin{tabular}{|c|r|r|r|r|r|r|}
\hline INDEX & \multicolumn{2}{|c|}{$\begin{array}{c}\text { vs. Communication } \\
\text { Abstracts }\end{array}$} & \multicolumn{2}{c|}{ vs. ComIndex } & \multicolumn{2}{c|}{ vs. ComAbstracts } \\
\hline & $\begin{array}{c}\text { UNIQUE } \\
\text { HITS }\end{array}$ & $\begin{array}{c}\text { SHARED } \\
\text { HITS }\end{array}$ & $\begin{array}{c}\text { UNIQUE } \\
\text { HITS }\end{array}$ & $\begin{array}{c}\text { SHARED } \\
\text { HITS }\end{array}$ & $\begin{array}{c}\text { UNIQUE } \\
\text { HITS }\end{array}$ & $\begin{array}{c}\text { SHARED } \\
\text { HITS }\end{array}$ \\
\hline ArticleFirst & 1,148 & 473 & 1,005 & 616 & 1,069 & 552 \\
\hline Academic Search Elite & 644 & 377 & 492 & 529 & 523 & 498 \\
\hline OmniFile & 81 & 24 & 77 & 28 & 94 & 11 \\
\hline Web of Science & 1,062 & 415 & 965 & 512 & 1,024 & 453 \\
\hline Ingenta & 1,169 & 486 & 1,000 & 655 & 1,086 & 569 \\
\hline
\end{tabular}

NOTE: This table's axis has been rotated so that the databases under consideration are listed down the left-hand side and the indexes against which they are being compared are listed across the top.

TABLE VII-c. Full Cross-Database Comparison: Total and by Call Letter Grouping: Unique Hits for the Communication Studies and the Multi-Subject Databases $(n=2,126)$

\begin{tabular}{|c|c|c|c|c|c|c|c|}
\hline INDEX & $\begin{array}{c}\text { TOTAL } \\
\text { UNIQUE } \\
\text { HITS }\end{array}$ & $\begin{array}{c}\text { \% OF } \\
\text { TOTAL } \\
\text { HITS }\end{array}$ & $\begin{array}{c}\text { HITS } \\
\text { CALL } \\
\text { LETTER } \\
\text { "B" }\end{array}$ & $\begin{array}{c}\text { HITS } \\
\text { CALL } \\
\text { LETTER } \\
\text { "H" }\end{array}$ & $\begin{array}{c}\text { HITS } \\
\text { CALL } \\
\text { LETTER } \\
\text { "P" }\end{array}$ & $\begin{array}{c}\text { HITS } \\
\text { CALL } \\
\text { LETTER } \\
\text { "PN" }\end{array}$ & $\begin{array}{c}\text { HITS } \\
\text { CALL } \\
\text { LETTER } \\
\text { "MISC" }\end{array}$ \\
\hline Communication Abstracts & 5 & 0.9 & 0 & 1 & 0 & 2 & 2 \\
\hline ComIndex & 19 & 2.6 & 1 & 1 & 11 & 5 & 1 \\
\hline ComAbstracts & 5 & 0.8 & 0 & 0 & 3 & 1 & 1 \\
\hline ArticleFirst & 36 & 2.2 & 6 & 21 & 4 & 2 & 3 \\
\hline Academic Search Elite & 7 & 0.7 & 2 & 2 & 1 & 1 & 1 \\
\hline OmniFile & 1 & 1.0 & 0 & 1 & 0 & 0 & 0 \\
\hline Web of Science & 41 & 2.8 & 12 & 12 & 10 & 3 & 4 \\
\hline Ingenta & 66 & 4.0 & 2 & 23 & 18 & 16 & 7 \\
\hline
\end{tabular}

the multi-subject databases, excluding of course OmniFile, one-half to two-thirds of what they covered is not covered by one of the Communication Studies indexes. So, while one might be tempted to suggest, on the basis of the results in Table VII-a, that one of the Communication Studies indexes might make a nice complement to one of the multi-subject databases, the truth of the matter is that the multi-subject databases actually make a necessary complement to the Communication Studies indexes, though one might also suggest that the larger multi-subject databases render the Communication Studies indexes moot. 
Perhaps the last argument that one might advance in favor of the Communication Studies indexes would be that, with their greater in-depth coverage of the discipline, they provide truly unique indexing; i.e., indexing for articles not covered in any of the other databases. To determine whether this might indeed be the case, in Table VII-c the authors compared the coverage provided by each of the databases against the coverage provided by the whole of the other databases. ${ }^{11}$ As the sub-table reveals, this argument in favor of the Communication Studies indexes does not seem to be valid and that, in fact, each of the indexes covers very little ground that is not covered by at least one other index/database. The specialization of the Communication Studies indexes does not, at least from the perspective of the researchers employed for this study, provide a unique avenue into the more esoteric, little-indexed but still useful regions of the Communication Studies journal literature.

\section{CONCLUSIONS}

Thus, it would seem, from the perspective of the Communication Studies researcher, that the small, discipline-specific indexes for Communication Studies have largely lost their relevance. The indexing strategy of ComIndex and ComAbstracts, which focuses on comprehensive indexing for core titles, seems to be superior to Communication Abstracts' strategy, which focuses on the sampling of several disciplines for Communication Studies articles, but in truth both the indexes and their strategies were overwhelmed by the large, multi-disciplinary, online databases employed herein. They would seem, at best, an adjunct to the mid-sized multi-subject databases like Academic Search Premier and Web of Science, ${ }^{12}$ and one would be hard pressed to argue a larger role for them. Unless one were to combine their indexing strategies in a single index, as some of the other discipline-specific indexes do, to greatly increase the amount of retrospective indexing they perform, and/or to alter their strategies to include more indexing of the obscurer titles of the field, one would be hard pressed from the perspective of the Communication Studies researcher to argue, in terms of the coverage that they provide, for the small Communication Studies indexes' continued relevance. It may well be that Communication Studies or, more likely, the indexing environment itself, has passed the smaller indexes by.

Received: $12 / 18 / 03$

Accepted: 03/18/04 


\section{ENDNOTES}

1. It would be customary at this point to introduce a review of literature. Unfortunately, we were able to locate only one other recent review of the indexes pertinent to Communication Studies, an article by Albert LaRose, and so thought it best that we address this sole article in a short note. In his study, LaRose gathered titles from a year's worth of issues from 12 core communication studies journals. Using these citations he tested the inclusiveness of eight indexes relevant to communication studies research. His results indicated varying degrees of selectivity in all of the indexes. Most startling was the discovery that nearly a quarter of the articles from these core journals were not included in any of the indexes (LaRose 1989).

2. Titles that were not selected for inclusion tended to be not as widely held or to not employ bibliographic formats that lent themselves to easy inclusion in our study: for example, the many titles in Journalism and in Communications Law that we had hoped to include tended to have lengthy, comment-laden endnotes or to employ ungainly footnotes rather than regularly formatted reference pages.

3 . In some instances, the first issue of 2000 was not available, so we employed later issues from 2000 or a late issue from 1999. For a few of the selected journals, we used reference pages from other issues because the articles in the titles' first issue were unsuitable: for example, one title's first issue for the year presented a review of classic articles from earlier decades. For a handful of the selected journals, we attempted to bolster their numbers by employing the bibliographies from more than one issue; conversely, for some journals we did not select all of the available reference pages in an issue because the titles provided so many more citations than did the issues from the other selected journals.

4. A quick review of the journal lists for the two indexes shows that ComAbstracts indexes 65 of the 83 titles that ComIndex covers (CIOS Support Staff "Indexes to ..." and "ComAbstracts").

5. All percentages presented in this article and its tables, with the exception of obvious casual estimations in the text, have been rounded to the nearest tenth of one percent.

6. One should note that only 57 articles from 2000 were cited, a comparatively insignificant number, so we will largely be ignoring them.

7. Call Letter Group "P" contains one title with the call letters "PE" that probably more properly belongs to Linguistics than to Communication Studies, but the other twenty-two titles have call numbers that begin with "P."

8. The multi-subject indexes in this study were selected upon the basis of their availability to the authors, and their inclusion should not be construed as an endorsement of any sort on the part of authors.

9. Communication Abstracts covered a bit over 100 academic journals (Gordon 1978) and provided 1,000 abstracts in 1978 (Communication Abstracts 1978). The source list for the 2002 volume listed 144 titles ("Source List . .." 2002), and the volume contained 1,950 abstracts (Communication Abstracts 2002).

10. There are two interesting anomalies in the results for the multi-subject databases: the comparatively poor coverage of the " $\mathrm{H}$ " group by Academic Search Elite and of the "B" group by Ingenta. Academic Search Elite's lapse could perhaps be accounted for by EBSCO's covering at least part of the " $\mathrm{H}$ " call number range with its Business Search Elite and Business Search Premier products. We can hazard no expla- 
nation for why Ingenta, which covers the other groups so exceptionally well, covers the "B" group so poorly.

11. As ComIndex and ComAbstracts are largely the same index in terms of the journals that they cover, they were not compared against one another in producing Table VII-c. Thus, ComAbstracts may have just one unique hit when compared against ComIndex in Table VII-a but five unique hits in Table VII-c.

12. Web of Science is, of course, a very large database, but its coverage is heavily slanted in favor of the sciences. One might argue that it is of mid-to-large size and more akin to Academic Search Elite than to ArticleFirst or Ingenta where the social sciences and/or the arts and humanities are concerned.

\section{REFERENCES}

Bisbee, Holly. 2003. <holly.bisbee@ ingenta.com>, "Updating question," private e-mail message to Signe Boudreau. (21 November 2003).

Block, Eleanor S. and James K. Bracken. 1991. Communication and the mass media: A guide to the reference literature. Englewood, Colorado: Libraries Unlimited.

Cambridge Scientific Abstracts. n.d. "Fact sheet: Communication Abstracts." < http:// www.csa.com/csa/factsheets/commabs.shtml>. (19 November 2003).

CIOS Support Staff. n.d. "About the ComAbstracts database." <http://www.cios. org/www/abinfo.htm>. (1 April 2002).

. n.d. "ComIndex Software Description." <http://www.cios.org/www/cidesc. htm>. (6 October 2003).

.n.d. "Comparing CIOS databases with databases from other vendors." $<$ http:// www.cios.org/www/abcomp.htm>. (6 October 2003).

. n.d. "Indexes to communication serials." <http://www.cios.org/www/comjour. htm>. (1 April 2002).

CIOS/Comserve support staff. 2003. <support@cios.org>, "Com Index \& Com Abstracts," private e-mail message to Signe Boudreau. (23 November 2003).

Clement, Elaine and Joyce L. Ogburn. 1995. "Searching GeoRef for archaeology." Behavioral \& Social Sciences Librarian 14 (1): 1-10.

Communication Abstracts. 1978. Communication Abstracts 1 (4): 545. 2002. Communication Abstracts. 25 (6): 874.

"Communication Abstracts: An international information source." 2002. Communication Abstracts 25 (1): [2].

Craig, Robert T. 1999. "Communication theory as a field." Communication Theory 9 (2): $119-161$.

EBSCO Publishing. 2003. "Database help." Available via: Academic Search Elite [database online]. (19 November 2003).

EBSCO Publishing Technical Support. 2003. <eptechsupport@epnet.com>, "Information [sic] about Academic Search Elite," private e-mail message to Signe Boudreau. (24 November 2003).

Gordon, Thomas F. 1978. "Introduction." Communication Abstracts 1 (1): [3].

Ingenta. n.d. "About Ingenta." <http://www.ingenta.com/about.htm>. (5 October 2003). 
ISI Help Desk-Americas. 2003. <ISIHelpDesk-Americas@isinet.com>, "Web of Science-number of citations \#55500," private e-mail message to Signe Boudreau. (20 November 2003).

LaGuardia, Cheryl. 2002. Magazines for libraries. New Providence, New Jersey: R.R. Bowker.

LaRose, Albert J. 1989. "Inclusiveness of indexes and abstracts of Internet to students of communication." $R Q 29$ (1): 29-35.

Mueller, Carolyn. 1984. "Communication journals." Serials Review 10 (4): 3-11.

OCLC. n.d. "ArticleFirst [OCLC]." < http://www.oclc.com/support/documentation/ firstsearch/databases/dbdetails/details/ArticleFirst.htm>. (6 October 2003).

Rubin, Rebecca B., Alan M. Rubin, and Linda J. Piele. 1996. Communication research: Strategies and sources. Belmont, California: Wadsworth Publishing.

Seiler, Berne. 2003. <bseiler@hwwilson.com>, "? about OmniFile FT Select," private e-mail message to Signe Boudreau. (24 November 2003).

"Source List, 2001/2002." 2002. Communication Abstracts 25 (5): 729-736.

Sutton, Ellen and Lori Foulke. 1999. "Coverage of anthropology by major electronic indexes: A comparison." Reference Services Review 27 (2): 134-157.

Thomson ISI. 2003. "Web of Science factsheet." <http://www.isinet.com/media/ presentrep/facts/WoS6.pdf>. (6 October 2003).

"Wilson OmniFile Full Text Mega Edition." n.d. <http://www.hwwilson.com/databases/ omnifile.htm>. (6 October 2003). 


\section{APPENDIX I. General Counts for the Project}

TOTALS:

Number of Selected Journals $=66$

Number of Citations, Total $=15,773$

Number of Journal Citations $=6,170$

Number of Bibliographies Selected $=421$

BY CALL LETTER GROUPS:

\#B Journals $=5$

\#MISC Citations to Journals $=781$

\#B Citations total $=1,123$

\#B Citations to Journals $=516$

\#B Bibliographies $=46$

\#MISC Bibliographies $=37$

$\# P N$ Journals $=16$

$\# \mathrm{H}$ Journals $=15$

\#H Citations total $=3,597$

$\# \mathrm{H}$ Citations to Journals $=1,636$

$\#$ H Bibliographies $=103$

\#PN Citations total $=3,960$

\#PN Citations to Journals $=1,319$

\#PN Bibliographies $=105$

\#P Journals $=23$

\#MISC Journals $=7$

\#P Citations total $=5,408$

\#P Citations to Journals $=1,918$

\#MISC Citations total $=1,685$

\#P Bibliographies $=130$

RESULTS, PART I: TOTAL CITATIONS: 6,170

\section{BY CALL LETTER GROUPS: \\ B: 516 Percentage: $8.4 \%$ \\ H: 1,636 Percentage: $26.5 \%$ \\ P: 1,918 Percentage: $31.1 \%$ \\ PN: 1,319 Percentage: $21.4 \%$ \\ misc: 781 Percentage: $12.7 \%$}

RESULTS, PART II: TOTAL CITATIONS: 2,126

BY CALL LETTER GROUPS:

B: 164 Percentage: $7.7 \%$

H: 552 Percentage: $26.0 \%$

P: 685 Percentage: $32.2 \%$

PN: 428 Percentage: $20.1 \%$

misc: 297 Percentage: $14.0 \%$
BY DECADE GROUPS:

1960s and earlier: 294 Percentage: $4.8 \%$

1970s: $634 \quad$ Percentage: $10.3 \%$

1980s: $1,807 \quad$ Percentage: $29.3 \%$

1990s: $3,373 \quad$ Percentage: $54.5 \%$

2000: $57 \quad$ Percentage: $1.0 \%$

ABSOLUTE MISSES (zero hits for all indexes and databases, Part II subset only): 163 BY CALL LETTER GROUP: 13“"B," 48“H," 24"P," 55"PN," 23 "misc"

ABSOLUTE MISSES PERCENTAGE (Part II subset only): $7.7 \%$

BY CALL LETTER GROUP: 7.9\%"B," 8.7\%"H," 3.5\%"P," 12.9\%"PN," 7.7\%“misc" 
APPENDIX II. The Journals Selected for the Project

\begin{tabular}{|c|c|c|c|c|}
\hline $\begin{array}{l}\text { JOURNAL TITLES, } \\
\text { VOLUMES, and ISSUES }\end{array}$ & $\begin{array}{l}\text { LC CALL } \\
\text { NUMBER }\end{array}$ & $\begin{array}{l}\text { CALL } \\
\text { LETTER } \\
\text { GROUP }\end{array}$ & $\begin{array}{l}\text { \# SELECTED } \\
\text { BIBLIOGRAPHIES }\end{array}$ & $\begin{array}{c}\text { \# SELECTED } \\
\text { JOURNAL } \\
\text { CITATIONS }\end{array}$ \\
\hline $\begin{array}{l}\text { Etc.: a Review of General } \\
\text { Semantics, } 57,1-4\end{array}$ & B 840 & "B" & 17 & 19 \\
\hline Philosophy \& Rhetoric, 33, 1 & B 1 & "B" & 7 & 41 \\
\hline Argumentation, 14, 1 and 2 & $\mathrm{BC} 1$ & "B" & 6 & 36 \\
\hline $\begin{array}{l}\text { Journal of Memory and } \\
\text { Language, } 42,1\end{array}$ & BF 455 & "B" & 7 & 221 \\
\hline $\begin{array}{l}\text { Journal of Nonverbal } \\
\text { Behavior, } 24,1 \text { and } 2\end{array}$ & BF 353 & "B" & 9 & 199 \\
\hline Human Relations, 53, 1 & $\mathrm{H} 1$ & "H" & 4 & 135 \\
\hline Science Communication, 22, 1 & H 62 & "H" & 4 & 49 \\
\hline $\begin{array}{l}\text { Management Communication } \\
\text { Quarterly, } 14,1\end{array}$ & HD 30.3 & "H” & 7 & 118 \\
\hline $\begin{array}{l}\text { Telecommunications Policy, } \\
24,2\end{array}$ & HE 7601 & "H” & 5 & 19 \\
\hline $\begin{array}{l}\text { Business Communication } \\
\text { Quarterly, 63, } 1 \text { and } 2\end{array}$ & HF 5718 & "H” & 17 & 117 \\
\hline $\begin{array}{l}\text { International Journal of } \\
\text { Advertising, } 19,1\end{array}$ & HF 5801 & "H” & 6 & 108 \\
\hline $\begin{array}{l}\text { Journal of Advertising } \\
\text { Research, } 40,1 \text { and } 2\end{array}$ & HF 5801 & "H” & 10 & 87 \\
\hline $\begin{array}{l}\text { Journal of Business and } \\
\text { Technical Communication, 14, } 1\end{array}$ & HF 5717 & "H” & 6 & 79 \\
\hline $\begin{array}{l}\text { Journal of Consumer Research, } \\
27,1\end{array}$ & HF 5415.3 & "H” & 9 & 213 \\
\hline $\begin{array}{l}\text { Journal of Current Issues and } \\
\text { Research in Advertising, 22, } 1\end{array}$ & HF 5801 & "H” & 5 & 181 \\
\hline The Journal of Advertising, 29, 1 & HF 5801 & "H" & 6 & 138 \\
\hline $\begin{array}{l}\text { Human Communication } \\
\text { Research, } 26,1\end{array}$ & HM 258 & "H” & 8 & 200 \\
\hline $\begin{array}{l}\text { Journal of Applied } \\
\text { Communication Research, 28, } 1\end{array}$ & HM 258 & "H” & 4 & 76 \\
\hline Media, Culture, \& Society, 22, 1 & HM 258 & "H" & 6 & 25 \\
\hline Public Opinion Quarterly, 64, 1 & HM 261 & "H" & 6 & 91 \\
\hline $\begin{array}{l}\text { Communication Reports, } 13,1 \\
\text { and } 2\end{array}$ & P 91.5 & "P" & 10 & 177 \\
\hline Communication Research, 27, 1 & P 91 & "P" & 4 & 157 \\
\hline $\begin{array}{l}\text { Communication Research } \\
\text { Reports, } 16,4\end{array}$ & P 87 & "P" & 11 & 204 \\
\hline Communication Theory, 10, 1 & P 87 & "P" & 6 & 98 \\
\hline $\begin{array}{l}\text { Critical Studies in Media } \\
\text { Communication, } 17,1\end{array}$ & P 87 & "P" & 5 & 13 \\
\hline Discourse \& Society, 11,1 & P 302 & "P" & 5 & 59 \\
\hline Discourse Processes, 30, 1 & P 302 & "P" & 3 & 117 \\
\hline
\end{tabular}




\begin{tabular}{|c|c|c|c|c|}
\hline $\begin{array}{l}\text { JOURNAL TITLES, } \\
\text { VOLUMES, and ISSUES }\end{array}$ & $\begin{array}{l}\text { LC CALL } \\
\text { NUMBER }\end{array}$ & $\begin{array}{l}\text { CALL } \\
\text { LETTER } \\
\text { GROUP }\end{array}$ & $\begin{array}{l}\text { \# SELECTED } \\
\text { BIBLIOGRAPHIES }\end{array}$ & $\begin{array}{l}\text { \# SELECTED } \\
\text { JOURNAL } \\
\text { CITATIONS }\end{array}$ \\
\hline $\begin{array}{l}\text { European Journal of } \\
\text { Communication, } 15,1\end{array}$ & P 91.3 & "P" & 4 & 47 \\
\hline Journal of Communication, 50, 1 & P 87 & "P" & 6 & 163 \\
\hline $\begin{array}{l}\text { Journal of Communication } \\
\text { Inquiry, } 24,1\end{array}$ & P 87 & "P" & 5 & 47 \\
\hline $\begin{array}{l}\text { Journal of Language and Social } \\
\text { Psychology, } 19,1\end{array}$ & P 40 & "P" & 7 & 188 \\
\hline $\begin{array}{l}\text { Journal of Mass Media Ethics, } \\
15,1\end{array}$ & P 94 & "P" & 4 & 30 \\
\hline Journal of Popular Culture, 33, 3 & P 87 & "P" & 7 & 6 \\
\hline $\begin{array}{l}\text { Language \& Communication, } \\
20,1\end{array}$ & P 87 & "P" & 4 & 58 \\
\hline $\begin{array}{l}\text { Mass Communication \& Society, } \\
3,1\end{array}$ & P 87 & "P" & 5 & 186 \\
\hline Media Asia, 27, 1 & P 92 & "P" & 4 & 17 \\
\hline Nordicom Review, 22, 1 & P 91.5 & "P" & 9 & 46 \\
\hline $\begin{array}{l}\text { Research on Language } \\
\text { and Social Interaction, 33, } 1\end{array}$ & $\mathrm{P} 1$ & "P" & 4 & 40 \\
\hline The Communication Review, 4, 1 & P 87 & "P" & 9 & 42 \\
\hline $\begin{array}{l}\text { The Howard Journal } \\
\text { of Communications, } 11,1\end{array}$ & P 87 & "P" & 4 & 97 \\
\hline $\begin{array}{l}\text { The Journal of Media Economics, } \\
13,1\end{array}$ & P 96 & "P" & 4 & 20 \\
\hline $\begin{array}{l}\text { Women's Studies in } \\
\text { Communication, 23, } 1\end{array}$ & P 96 & "P" & 6 & 69 \\
\hline American Speech, 75, 1 & PE 2801 & "P" & 4 & 37 \\
\hline $\begin{array}{l}\text { Argumentation and Advocacy, } \\
37,1\end{array}$ & PN 4001 & "PN" & 11 & 91 \\
\hline Communication Education, 49, 1 & PN 4071 & "PN" & 11 & 129 \\
\hline $\begin{array}{l}\text { Communication Monographs, } \\
67,1\end{array}$ & PN 4077 & "PN" & 6 & 143 \\
\hline Communication Quarterly, 48, 1 & PN 4071 & "PN" & 8 & 165 \\
\hline Communication Studies, 51, 1 & PN 4001 & "PN" & 5 & 81 \\
\hline Gazette, 62, 1 & PN 4699 & "PN" & 5 & 26 \\
\hline $\begin{array}{l}\text { Journal of Broadcasting } \\
\text { \& Electronic Media, 44, } 1\end{array}$ & PN 1991 & "PN" & 10 & 214 \\
\hline $\begin{array}{l}\text { Journal of Popular Film } \\
\& \text { Television, } 28,1 \text { and } 2\end{array}$ & PN 1993 & "PN" & 11 & 12 \\
\hline $\begin{array}{l}\text { Journalism \& Communication } \\
\text { Monographs, } 1,4\end{array}$ & PN 4722 & "PN" & 2 & 31 \\
\hline $\begin{array}{l}\text { Journalism \& Mass } \\
\text { Communication Educator, 55, } 1\end{array}$ & PN 4788 & "PN" & 6 & 56 \\
\hline $\begin{array}{l}\text { Quarterly Journal of Speech, } \\
86,3\end{array}$ & PN 4071 & "PN" & 4 & 63 \\
\hline Rhetoric Society Quarterly, 30, 1 & PN 171.4 & "PN" & 4 & 28 \\
\hline
\end{tabular}


APPENDIX II (continued)

\begin{tabular}{|l|c|c|c|c|}
\hline \multicolumn{1}{|c|}{$\begin{array}{c}\text { JOURNAL TITLES, } \\
\text { VOLUMES, and ISSUES }\end{array}$} & $\begin{array}{c}\text { LC CALL } \\
\text { NUMBER }\end{array}$ & $\begin{array}{c}\text { CALL } \\
\text { LETTER } \\
\text { GROUP }\end{array}$ & $\begin{array}{c}\text { \# SELECTED } \\
\text { BIBLIOGRAPHIES }\end{array}$ & $\begin{array}{c}\text { \# SELECTED } \\
\text { JOURNAL } \\
\text { CITATIONS }\end{array}$ \\
\hline $\begin{array}{l}\text { Southern Communication } \\
\text { Journal, 66, } 1\end{array}$ & PN 4071 & "PN" & 7 & 114 \\
\hline $\begin{array}{l}\text { Text and Performance Quarterly, } \\
20,1\end{array}$ & PN 2 & "PN" & 6 & 34 \\
\hline $\begin{array}{l}\text { Western Journal } \\
\text { of Communication, 64, 1 }\end{array}$ & PN 4071 & "PN" & 5 & 90 \\
\hline Written Communication, 17, 1 & PN 211 & "PN" & 4 & 42 \\
\hline Political Communication, 17, 1 & JF 1525 & "misc" & 4 & 83 \\
\hline Popular Music and Society, 24, 1 & ML 1 & "misc" & 4 & 12 \\
\hline Health Communication, 12, 1 & R 118 & "misc" & 5 & 146 \\
\hline $\begin{array}{l}\text { American Journal of Speech- } \\
\text { Language Pathology, 10, 1 }\end{array}$ & RC 423 & "misc" & 10 & 149 \\
\hline $\begin{array}{l}\text { Journal of Communication } \\
\text { Disorders, 33, } 1\end{array}$ & RC 423 & "misc" & 4 & 206 \\
\hline $\begin{array}{l}\text { Journal of Speech, Language, } \\
\text { and Hearing Research, 43, } 1\end{array}$ & RC 423 & "misc" & 5 & 151 \\
\hline The Information Society, 16, 1 & Z 668 & "misc" & 5 & 34 \\
\hline
\end{tabular}

